\title{
Choosing Wisely Canada Students and Trainees Advocating for Resource Stewardship (STARS) campaign: a descriptive evaluation
}

\author{
Franco Cardone BSc, Daphne Cheung BSc, Angela Han BSc, Karen B. Born PhD, Lisa Alexander MD, \\ Wendy Levinson MD, Brian M. Wong MD
}

\section{Abstract}

Background: Resource stewardship is being increasingly recognized as an essential competency for physicians, but medical schools are just beginning to integrate this into education. We describe the evaluation of Choosing Wisely Canada's Students and Trainees Advocating for Resource Stewardship (STARS) campaign, a student-led campaign to advance resource stewardship education in medical schools across Canada.

Methods: We evaluated the campaign 6 months after its launch, in November 2015. STARS students were administered a telephone survey eliciting a description of the initiatives that they had implemented or planned to implement at their schools to promote resource stewardship, and exploring their perceptions of facilitators of and barriers to successful implementation of their initiatives. We used a mixed-methods approach to analyze and summarize the data.

Results: Twenty-seven (82\%) of the 33 eligible students representing all 17 medical schools responded. In 14 schools (82\%), students led various local activities (e.g., interest groups, campaign weeks) to raise awareness about resource stewardship among medical students and faculty. Students contributed to curriculum change (both planned and implemented) at 10 schools (59\%). Thematic analysis revealed key program characteristics that facilitated success (e.g., pan-Canadian student network, local faculty champion) as well as barriers to implementing change (e.g., complex processes to change curriculum, hierarchical nature of medical school).

Interpretation: This student-led campaign, with support from local faculty and Choosing Wisely Canada staff, led to awarenessbuilding activities and early curricula change at medical schools across Canada. Future plans will build on the initial momentum created by the STARS campaign to sustain and spread local initiatives.

hoosing Wisely Canada is a campaign that promotes resource stewardship by helping physicians and patients engage in conversations about unnecessary tests and treatments. ${ }^{1}$ Physicians' ordering behaviours and resource use are strongly influenced by practices that they were exposed to during training. ${ }^{2,3}$ In addition, the Royal College of Physicians and Surgeons of Canada updated its CanMEDS Physician Competency Framework in 2015 and now clearly identifies resource stewardship as a key physician competency within the "Leader" role that must be addressed in residency training. ${ }^{4}$ However, given that these changes are relatively recent, many curricula and residency programs at Canadian medical schools do not have consistent content on resource stewardship..$^{5,6} \mathrm{~A}$ recent survey showed that US medical students feel that physicians have a responsibility to contribute to health care system stewardship and should play a more prominent role in reducing unnecessary care. ${ }^{7}$
Given the importance of training in establishing practice habits and the gap in medical curricula, Choosing Wisely Canada established medical education as a key strategic priority. As a first step, Choosing Wisely Canada partnered with national medical student associations to release a list of "Six things medical students and trainees should question" to highlight the importance of integrating resource stewardship in medical education. ${ }^{8}$ Next, in November 2015, Choosing Wisely Canada launched the Students and Trainees Advocating for Resource Stewardship (STARS) campaign (see Box 1

Competing interests: None declared.

This article has been peer reviewed.

Correspondence to: Karen Born, karen.born@utoronto.ca

CMAJ Open 2017. DOI:10.9778/cmajo.20170090 
for a detailed overview and Table 1 for the key program elements) and engaged 2 medical students from each of Canada's 17 medical schools to catalyze grassroots, student-led initiatives to advance resource stewardship in medical education at their schools. The main objectives of this descriptive study were to 1) describe how the STARS campaign was implemented, 2) summarize the STARS initiatives and 3) identify systemic facilitators and barriers encountered by STARS students that could guide the improvement of the STARS campaign to optimize its impact.

\section{Methods}

\section{Study design and sources of data}

This descriptive study consisted of a telephone survey of STARS students (Appendix 1, available at www.cmajopen.ca/ content/5/4/E864/suppl/DC1) and 1 question emailed to all medical school deans. The student survey elicited a description of the initiatives that the students had implemented or planned to implement at their schools to promote resource stewardship. The survey also explored the students' perceptions of facilitators of and barriers to successful implementa-

\section{Box 1: Overview of Students and Trainees Advocating for}

\section{Resource Stewardship (STARS) campaign}

- Choosing Wisely Canada leadership communicated with the deans of all 17 medical schools to inform them about STARS and asked each of them to sponsor 2 medical students to participate in the campaign.

- Students were then recruited to apply through an open call using local medical school email distribution lists and social media, facilitated by the Canadian Federation of Medical Students (CFMS) and Fédération médicale étudiante du Québec (FMÉQ).

- 33 students were selected (16 medical schools sponsored 2 student leaders, and 1 medical school sponsored 1 student leader) from the 114 applications received to attend a 1-day Leadership Summit hosted by Choosing Wisely Canada. Wherever possible, 1 first-year and 1 second-year student from each school were selected. The rationale was that this would allow first-year students to carry forward and facilitate sustainability of STARS initiatives at their schools. Secondyear students also have more experience and may have more reach within the student body.

- The deans at each of the medical schools funded all travelrelated costs for their school's students.

- The CFMS and FMÉQ both identified a student to represent the organization and participate in the summit.

- The main goals of the Leadership Summit were to introduce student leaders to core resource stewardship principles and the broader Choosing Wisely Canada campaign, and to equip them with leadership, advocacy and communication skills to launch grassroots initiatives at their local schools to promote resource stewardship.

- Additional program elements, such as Cloud-based resource sharing, ongoing communication through social media and teleconferences, and identification of faculty to support STARS student-led activities, supported local change efforts and fostered the establishment of a pan-Canadian network of STARS students. tion of their initiatives, and included open-ended questions to solicit feedback on the usefulness of the various program elements (Table 1). We pilot-tested the survey with 3 past Choosing Wisely Canada summer students and modified the survey accordingly.

We invited all STARS students to participate. Two summer students (D.C. and F.C.) administered the survey. To minimize bias, the summer students who collected the data were not involved in the organization of STARS. When possible, students from the same school answered the survey together on the same call; however, some students responded individually owing to scheduling issues. Interviews ranged from 30 minutes to 1 hour in duration. We audiorecorded the telephone conversations to ensure accuracy of data collection and entered numeric and narrative data into our study database, removing any potential identifying information. Student participants were anonymized to ensure confidentiality.

We asked the deans for a narrative description of the impact of STARS at their school in order to triangulate data collected from our medical student questionnaire. We expected that an in-depth questionnaire would result in a low response rate given how busy the deans are and so elected to send them the following question and asked them to provide a detailed response: "What impact have the STARS students had with respect to resource stewardship at your medical school?"

\section{Descriptive analysis}

We used descriptive statistics to summarize survey results, employing counts and percentages to summarize results. The medical school was the unit of analysis, and so in cases in which 2 students from the same school responded, we combined their responses. We analyzed the open-ended narrative responses from STARS students and deans inductively using a thematic analysis. Three study team members (F.C., D.C., K.B.B.) independently read the interview transcripts and identified key themes regarding facilitators and barriers; consensus was reached through discussion. Our analysis was reflexively mindful of our own subject positions in the research context; we remained cognizant of the forces that affected our analysis of the data (e.g., our own sex, professional roles and social positions). In particular, 3 coauthors (B.W., K.B.B., W.L.) hold national leadership positions in Choosing Wisely Canada, and 1 student coauthor is enrolled in a physician leadership stream in our medical school.

\section{Ethics approval}

The study was approved by the University of Toronto Research Ethics Board.

\section{Results}

Twenty-seven (82\%) of the 33 students representing the 17 medical schools provided consent and responded to the survey. Students who did not participate were unavailable owing to logistical reasons or did not respond to the interview request. In 19 cases, students from the same school answered the survey together on the same telephone call, and 8 students 
responded individually. Of the 27 students, 17 were women and 10 were men. Fourteen will graduate in 2019, 12 will graduate in 2018, and 1 graduated in 2017. Eleven (65\%) of the 17 deans or a delegate responded to the email request.

\section{Student-led initiatives}

Students at 6 schools (35\%) planned curricular changes. Planning activities included meeting with educational leaders, reviewing course materials to highlight existing resource

\begin{tabular}{|c|c|}
\hline Element & Description \\
\hline \multicolumn{2}{|c|}{ Capacity-building activities and resources } \\
\hline STARS Leadership Summit & $\begin{array}{l}\text { 1-day meeting bringing together } 2 \text { student representatives } \\
\text { from each medical school that equipped students with } \\
\text { knowledge about resource stewardship as well as } \\
\text { leadership, advocacy and communication skills to support } \\
\text { implementation of local student-led Choosing Wisely } \\
\text { Canada initiatives. }\end{array}$ \\
\hline $\begin{array}{l}\text { "Six things medical students and } \\
\text { trainees should question" }\end{array}$ & $\begin{array}{l}\text { Choosing Wisely Canada list for medical education } \\
\text { endorsed by CFMS and FMÉQ and made available to all } \\
\text { STARS students through the Choosing Wisely Canada } \\
\text { website. }\end{array}$ \\
\hline \multicolumn{2}{|c|}{ Community-building activities and resources } \\
\hline Conference calls & $\begin{array}{l}\text { Teleconferences every } 2 \text { mo to provide STARS students } \\
\text { with a forum to share ideas and ask the national student } \\
\text { community for advice related to their initiatives. }\end{array}$ \\
\hline Facebook group & $\begin{array}{l}\text { Private Facebook group to allow STARS students to stay in } \\
\text { contact with each other and share resources related to their } \\
\text { initiatives. Students could also post photographs of STARS } \\
\text { events at their schools to showcase their initiatives and } \\
\text { successes to other STARS students. }\end{array}$ \\
\hline Shared Google document & $\begin{array}{l}\text { Shared Google Doc created by } 1 \text { of the STARS students to } \\
\text { provide students with a summary of ongoing STARS } \\
\text { activities at each school across Canada. Students updated } \\
\text { this document with their planned and completed initiatives, } \\
\text { resources, and tips for success and lessons learned. }\end{array}$ \\
\hline $\begin{array}{l}\text { Collaboration through STARS } \\
\text { community of practice }\end{array}$ & $\begin{array}{l}\text { Outside of the conference calls, Facebook group and } \\
\text { Google Doc, some STARS students worked collaboratively } \\
\text { with students from other schools on common initiatives. } \\
\text { These included 1-on-1 interactions and group interactions } \\
\text { via videoconference (i.e., group Skype calls). }\end{array}$ \\
\hline $\begin{array}{l}\text { National medical student } \\
\text { organizations (CFMS, FMÉQ) }\end{array}$ & $\begin{array}{l}\text { Integration of Choosing Wisely Canada principles into } \\
\text { FMÉQ Charter, approval and publication of a CFMS } \\
\text { Choosing Wisely Position Paper, and engagement of } \\
\text { CFMS and FMÉQ liaison representatives to provide } \\
\text { ongoing endorsement of the STARS program and student } \\
\text { initiatives. }\end{array}$ \\
\hline \multicolumn{2}{|c|}{ School-based activities and resources } \\
\hline Other medical students & $\begin{array}{l}\text { Local medical students were recruited by STARS students } \\
\text { to help plan and implement local STARS initiatives. }\end{array}$ \\
\hline Faculty mentor/advisor & $\begin{array}{l}\text { Faculty mentor/advisor to mentor STARS students locally } \\
\text { and support their change efforts. Some students were able } \\
\text { to identify a faculty mentor themselves. For students } \\
\text { without a faculty mentor, Choosing Wisely Canada reached } \\
\text { out to its network of Choosing Wisely Canada clinical leads } \\
\text { to identify faculty who could support student efforts locally. }\end{array}$ \\
\hline Medical school leadership & $\begin{array}{l}\text { Deans and department chairs at each medical school } \\
\text { provided support to STARS students attempting to navigate } \\
\text { the process of curricular change. }\end{array}$ \\
\hline
\end{tabular}


stewardship content or identify opportunities to integrate resource stewardship principles, and carrying out needs assessment. At 4 schools (24\%), students successfully implemented curricular changes, including the introduction of resource stewardship content into small-group learning sessions, lectures and clinical skills sessions.

Many students led a variety of other initiatives intended to raise awareness of and generate interest in Choosing Wisely Canada and resource stewardship. Since STARS was designed to be grassroots and student-led, initiatives varied substantially across schools (Table 2), reflecting the personal interests of the students as well as the unique educational environment of each school. Examples of student-led initiatives included creating a Choosing Wisely Canada student interest group (implemented at 2 schools [12\%] and approved at 4 schools [24\%]), organizing a campaign week to raise awareness about Choosing Wisely Canada and resource stewardship (4 schools [24\%]), publishing newsletters or blogs about resource stewardship (3 schools [18\%]), organizing special presentations on resource stewardship (6 schools [35\%]) and introducing articles focused on resource stewardship in journal club discussions (2 schools [12\%]). In additional, at 8 schools (47\%), students performed a needs assessment (outside of curriculum planning activities) to determine baseline student knowledge and attitudes with regard to resource stewardship.

\section{Medical school deans' perceptions}

The nature of the deans' responses did not provide sufficient detail to allow for rigorous thematic analysis. In several cases, deans provided a summary that they had asked their STARS students to prepare. However, their responses gave the impression that they were aware of the STARS students' contributions and that they had a favourable view of the STARS campaign in general.

\section{Facilitators of student-led initiatives}

Table 3 summarizes STARS program elements and student perceptions of how these facilitated successful implementation of their STARS initiatives. Overall, program elements fell into 3 broad categories. First, there were program elements students felt were extremely helpful in facilitating their overall success. For example, students reported that the Leadership Summit itself was essential and provided the foundational knowledge and skills to create change. The summit also contributed to establishing a pan-Canadian network of STARS students. Students recounted numerous examples of connecting with each other both in person and through videoconference in order to share resources, provide peer feedback and, in some instances, work together to organize interschool activities. Students also described the conference calls that took place every 2 months as a highly useful forum to discuss project progress and seek advice from other students and Choosing Wisely Canada leadership.

Second, some program elements, particularly those based at the local medical school, were perceived to be helpful facilitators but were not consistently accessible or available to all students. For example, at 10 schools (59\%), students had support from a local faculty mentor, which was critical to their overall success. They described finding like-minded faculty engaged in aligned work to be akin to finding "an ally."

Finally, some program elements, although generally seen as "nice to have," were not perceived to be critical facilitators of students' overall success in implementing change at their school. For example, the Facebook group, which was widely accessed by students, was seen as a nice venue to share stories and provide updates but was not frequently used by students to seek advice from one another.

\section{Barriers to implementation of student-led initiatives}

Students identified barriers to implementing STARS initiatives at their medical schools (Table 4), which we grouped into 3 broad categories: 1) students limited as change agents, 2) curricular change is complex and 3) structural barriers. The multiple commitments and competing demands of medical school left some students with limited time to lead local initiatives and implement curricular change. Students also expressed difficulty recommending changes to the curriculum for upper-year students when they themselves had not yet reached that stage of medical training. A few students reported that it was difficult to influence change at their schools owing to the perceived hierarchical nature of medical school.

Students who struggled to initiate curricular change found it difficult to navigate the complexities of medical school administration. For some, advocating to incorporate resource stewardship as a new topic was seen as competing for limited curricular time. Furthermore, several schools are undergoing curricular reform, such that the introduction of new content was not seen to be a priority.

Finally, structural barriers, which included local policies and logistical challenges, also posed problems. For example, many schools have deadlines for proposals to approve new interest groups, and these had already elapsed by the time students returned from the Leadership Summit.

\section{Interpretation}

Within a relatively short time, STARS students implemented a wide range of awareness-building activities and initiated plans to integrate, and in several cases added, resource stewardship content into the curriculum. These findings suggest that a national grassroots campaign that capitalizes on student advocacy and leadership can accelerate change and serve as a catalyst to address the urgent need to teach medical students about resource stewardship. STARS students clearly self-identified as leaders, and the time spent learning together in-person at the leadership summit and cocreating a vision for STARS was highly beneficial and led to the establishment of a national network of STARS students. We believe that this pan-Canadian network, with Choosing Wisely Canada playing a key central coordination role, served to fuel the implementation of local initiatives by providing students with a sounding board and a forum that they could turn to for advice and support. 


\begin{tabular}{|c|c|c|}
\hline Initiative & $\begin{array}{l}\text { No. }(\%) \text { of } \\
\text { medical } \\
\text { schools }\end{array}$ & Description \\
\hline \multicolumn{3}{|c|}{ Curriculum change } \\
\hline Planned & $6(35)$ & $\begin{array}{l}\text { STARS students embarked on planning curricular changes through a variety of different } \\
\text { activities, including reaching out to educational leaders (i.e., vice deans, curricular leads) } \\
\text { and undergraduate medical education curriculum committees, reviewing course content } \\
\text { to identify opportunities to integrate resource stewardship content, and carrying out } \\
\text { formal (e.g., surveys, end-of-session feedback) and informal (e.g., informal } \\
\text { conversations) assessment of students' needs to ascertain their perceptions regarding } \\
\text { learning about resource stewardship. }\end{array}$ \\
\hline Implemented & $4(24)$ & $\begin{array}{l}\text { Curricular changes varied among schools, with some seeking to make changes to } \\
\text { current materials and others hoping to introduce entirely new learning activities. These } \\
\text { changes involved the inclusion of resource stewardship education into small-group } \\
\text { learning, such as problem-based learning and case-based learning, didactic lectures } \\
\text { and clinical skills sessions. }\end{array}$ \\
\hline \multicolumn{3}{|c|}{ Needs assessment } \\
\hline & $8(47)$ & $\begin{array}{l}\text { Students surveyed and held informal focus groups with their classmates to determine } \\
\text { their current level of knowledge regarding Choosing Wisely Canada and resource } \\
\text { stewardship. These were independent from needs-assessment activities tied to } \\
\text { curriculum planning. }\end{array}$ \\
\hline \multicolumn{3}{|l|}{ Interest group } \\
\hline Planned & $4(24)$ & $\begin{array}{l}\text { Interest groups were often in the planning stages because the students started their } \\
\text { work after the November Leadership Summit, and most schools require interest group } \\
\text { proposals to be submitted by October. However, } 4 \text { schools have confirmed they will } \\
\text { establish a student Choosing Wisely Canada interest group in the upcoming } \\
\text { academic year. }\end{array}$ \\
\hline Implemented & $2(12)$ & $\begin{array}{l}\text { Key activities include organizing guest speaker sessions, Choosing Wisely Canada } \\
\text { presentations and partnering with other groups with overlapping areas of interest, such } \\
\text { as the Students for Antimicrobial Stewardship interest group. }\end{array}$ \\
\hline \multicolumn{3}{|c|}{ Campaign week } \\
\hline Implemented & $4(24)$ & $\begin{array}{l}\text { Campaign-week activities differed among the various schools. Most decided to hold } \\
\text { guest speaker sessions, raise awareness through social media (blog, Facebook, } \\
\text { Twitter) and have in-class activities such as trivia contests. A few schools in } \\
1 \text { province decided to work together on a provincial Choosing Wisely Canada } \\
\text { campaign week. }\end{array}$ \\
\hline \multicolumn{3}{|c|}{ Awareness-building activities } \\
\hline Implemented & $4(24)$ & $\begin{array}{l}\text { Students published items related to Choosing Wisely Canada and resource stewardship } \\
\text { on social media and in student journals/newsletters and blogs, and also presented at } \\
\text { provincial medical student conferences. }\end{array}$ \\
\hline \multicolumn{3}{|c|}{ Special presentation on resource stewardship } \\
\hline Implemented & $6(35)$ & $\begin{array}{l}\text { Presentations organized by the students outside of the formal curriculum included talks } \\
\text { about Choosing Wisely Canada by physicians with first-hand experience, a half-day } \\
\text { resource stewardship conference and a session on how to be mindful of resources in } \\
\text { clinical practice. }\end{array}$ \\
\hline \multicolumn{3}{|l|}{ Journal club } \\
\hline Implemented & $2(12)$ & $\begin{array}{l}\text { Journal clubs organized by students involved the critical appraisal of research related to } \\
\text { resource stewardship in clinical practice. One school organized a stand-alone activity, } \\
\text { and another partnered with an existing journal club series and recommended an article } \\
\text { related to resource stewardship for discussion. }\end{array}$ \\
\hline \multicolumn{3}{|l|}{ Other } \\
\hline Implemented & $3(18)$ & $\begin{array}{l}\text { Advocacy-related activities such as monthly meetings with the dean and Medical } \\
\text { Society, and attending lobby days. }\end{array}$ \\
\hline
\end{tabular}


Table 3: Students' perceptions of facilitators of student-led initiatives and the usefulness of program elements of the Students and Trainees Advocating for Resource Stewardship campaign

\begin{tabular}{|c|c|c|}
\hline Theme & Student perception & Representative quote \\
\hline \multicolumn{3}{|c|}{ Elements perceived to be extremely helpful in facilitating students' success } \\
\hline Leadership Summit & $\begin{array}{l}\text { All students attended Leadership Summit, and most thought it was crucial to } \\
\text { their success } \\
\text { Workshops on leadership, advocacy and communication were essential to } \\
\text { developing skills required to succeed as part of STARS program } \\
\text { Some students felt that less time should have been spent on building STARS } \\
\text { mission statement, and more time listening to speakers and attending } \\
\text { workshops }\end{array}$ & $\begin{array}{l}\text { "[The leadership summit] gave structure to the } \\
\text { group .... there were a lot of workshops in the } \\
\text { introduction by [Choosing Wisely Canada staff] as } \\
\text { to what the focus of the campaign was, and this } \\
\text { was really helpful to determine what direction we } \\
\text { wanted to go in terms of resource stewardship." } \\
\text { (School 3) }\end{array}$ \\
\hline Conference calls & $\begin{array}{l}\text { Most students attended conference calls every } 2 \text { mo with Choosing Wisely } \\
\text { Canada staff and other STARS students } \\
\text { Calls were a great way to obtain high-level overview of activities planned at } \\
\text { other schools and to seek advice from larger STARS community and central } \\
\text { Choosing Wisely Canada team } \\
\text { Some students commented that the timing of calls during the day made it } \\
\text { difficult to attend } \\
\text { Students also felt that calls could have been structured with clearer objectives }\end{array}$ & $\begin{array}{l}\text { "It was a good hour-long investment where you } \\
\text { could learn a snapshot of what was going on, to } \\
\text { tell what you were doing, and then potentially get } \\
\text { help if you needed, and I thought that was really } \\
\text { effective". (School 4) }\end{array}$ \\
\hline $\begin{array}{l}\text { Collaboration through } \\
\text { pan-Canadian } \\
\text { STARS network }\end{array}$ & $\begin{array}{l}\text { Most students interacted with national STARS student network and found the } \\
\text { interaction to be very valuable } \\
\text { Students shared resources, provided peer-feedback and advice to others } \\
\text { encountering common challenges, and collaborated on interschool activities } \\
\text { (provincial campaign week, surveys) }\end{array}$ & $\begin{array}{l}\text { "They didn't want it just be that } 1 \text { conference and } \\
\text { go off and do your own thing; they wanted to have } \\
\text { that connection. I felt the community of practice } \\
\text { was good." (School 8) }\end{array}$ \\
\hline \multicolumn{3}{|c|}{ Elements perceived to be helpful facilitators but not consistently accessible or available to students } \\
\hline $\begin{array}{l}\text { Faculty mentor/ } \\
\text { advisor }\end{array}$ & $\begin{array}{l}\text { About half of the students worked closely with a faculty member and found his } \\
\text { or her support to be quite helpful } \\
\text { Faculty members helped by providing advice and guidance, advocating for } \\
\text { proposed changes and connecting STARS students with local stakeholders } \\
\text { Students who did not interact as closely with faculty leads at their home } \\
\text { institution wanted this support but had challenges scheduling meetings owing } \\
\text { to faculty unavailability, or had trouble engaging an actual lead at their school } \\
\text { Other students commented that they were not certain what the faculty lead's } \\
\text { role might be in helping with their initiative }\end{array}$ & $\begin{array}{l}\text { "Our faculty mentors have essentially pushed our } \\
\text { curricular change. It's been great to have an ally } \\
\text { who is an MD faculty". (School 4) } \\
\text { "It's hard to find a mentor on your own ... } \\
\text { somebody ... you can ask all these questions and } \\
\text { bother them." (School 12) }\end{array}$ \\
\hline $\begin{array}{l}\text { Other medical } \\
\text { students }\end{array}$ & $\begin{array}{l}\text { Some students found it helpful to engage other interested students at their } \\
\text { medical school to divide the workload associated with planning and } \\
\text { implementing STARS initiatives } \\
\text { Local medical students helped to organize and set up events and engage other } \\
\text { classmates, and provided insight on the upper years of medical school for } \\
\text { STARS students in preclerkship }\end{array}$ & $\begin{array}{l}\text { "The workload of enacting curricular change is } \\
\text { significant, and having } 2 \text { people, } 1 \text { of whom } \\
\text { entered clerkship soon after the STARS } \\
\text { conference, was a little bit difficult to make all of } \\
\text { the changes that we want to happen, so I was } \\
\text { really happy that we were able to bring in other } \\
\text { motivated students." (School } 4 \text { ) }\end{array}$ \\
\hline \multicolumn{3}{|c|}{ Elements seen as "nice to have" but not perceived to be critical facilitators of overall students' success } \\
\hline Facebook group & $\begin{array}{l}\text { All the students were part of Facebook group but did not perceive that the } \\
\text { information shared in the group advanced their local initiatives in a meaningful } \\
\text { way } \\
\text { Students appreciated the opportunity to receive updates on other STARS } \\
\text { initiatives and enjoyed seeing photographs of successful events } \\
\text { Many students thought Facebook group was not used to its full potential } \\
\text { because it was mostly used for passive information sharing and some of the } \\
\text { information had already been disseminated through other methods (email, } \\
\text { conference calls) } \\
\text { Students would have preferred more active collaboration using the Facebook } \\
\text { group } \\
\text { Some students mentioned that they do not used Facebook as much as they } \\
\text { had in the past }\end{array}$ & $\begin{array}{l}\text { "It was useful to be connected with other } \\
\text { students, but I wish it was used for more } \\
\text { discussion, and I guess it is hard to ... I think it is } \\
\text { better for planning or if they put up resources they } \\
\text { used ... I know also people put up pictures of } \\
\text { things like that. If it was used more like that, I } \\
\text { think it would have been more useful ... to keep } \\
\text { students all on the same page about what was } \\
\text { happening across the different universities. It } \\
\text { wasn't fully utilized." (School 1) }\end{array}$ \\
\hline $\begin{array}{l}\text { Shared Google } \\
\text { document }\end{array}$ & $\begin{array}{l}\text { Most students posted information related to their STARS initiatives on the } \\
\text { shared Google Doc at the beginning, but only a small proportion found it to be } \\
\text { useful } \\
\text { Main challenge was that students did not routinely update the information on } \\
\text { the Google Doc }\end{array}$ & $\begin{array}{l}\text { "I guess I can say initially it was quite nice to be } \\
\text { able to list all the initiatives as well as faculty } \\
\text { names as it was really organized, but I don't know } \\
\text { what happened after that; there wasn't really any } \\
\text { follow-up." (School 16) }\end{array}$ \\
\hline
\end{tabular}

Educational leaders have emphasized the importance of combining culture and curriculum change to promote resource stewardship in medical education. ${ }^{9}$ A recent systematic review identified the "creation of a supportive environ- ment in which ... the presence of role models of delivering high-value, cost-conscious care, and a culture of high-value, cost-conscious care reinforce the desired training goals" as critical to advancing resource stewardship education. ${ }^{10}$ The 


\begin{tabular}{|c|c|}
\hline Theme; subtheme & Representative quote \\
\hline \multicolumn{2}{|l|}{ Students limited as change agents } \\
\hline Multiple competing priorities & $\begin{array}{l}\text { "[A limitation was] our own time because we obviously have to } \\
\text { study medicine ... whilst undertaking curricular change." } \\
\text { (School 4) }\end{array}$ \\
\hline $\begin{array}{l}\text { Difficult to change a curriculum that } \\
\text { student has not yet participated in }\end{array}$ & $\begin{array}{l}\text { "Being in first year ... I don't have an understanding of what school } \\
\text { is like for third and fourth years, so personally trying to do } \\
\text { advocacy projects for curricular change and stuff like that is } \\
\text { difficult for me to push in third and fourth year." (School 17) }\end{array}$ \\
\hline $\begin{array}{l}\text { Hierarchy in medical education } \\
\text { (medical students at bottom) }\end{array}$ & $\begin{array}{l}\text { "We are medical students, and we don't have the influence } \\
\text { required for curricular change." (School 5) }\end{array}$ \\
\hline \multicolumn{2}{|l|}{ Curricular change is complex } \\
\hline Competing curricular demands & $\begin{array}{l}\text { "There are a lot of different interest groups trying to get a say in } \\
\text { the curriculum, so it is hard at this particular moment to kind of put } \\
\text { our voices forward ... we really need to vouch for why resource } \\
\text { stewardship might be more important than [other special interest } \\
\text { topics]" (School 5) }\end{array}$ \\
\hline $\begin{array}{l}\text { Undergraduate medical education } \\
\text { curriculum renewal/reform }\end{array}$ & $\begin{array}{l}\text { "I think people are a bit annoyed when you ask for yet another } \\
\text { change, and [our medical school] is already dealing with the } \\
\text { accreditation issue. So there are certain things that are higher } \\
\text { priorities for them." (School 14) }\end{array}$ \\
\hline \multicolumn{2}{|l|}{ Structural barriers } \\
\hline Policies and procedures & $\begin{array}{l}\text { "The Choosing Wisely campaign and the STARS conference was } \\
\text { after the deadline to apply to the interest group people at [our } \\
\text { school's] medical student society. ... I plan on applying for actual } \\
\text { status in the next application for interest groups." (School 14) }\end{array}$ \\
\hline Logistics and local resources & $\begin{array}{l}\text { "If you don't book your rooms for the whole year in September or } \\
\text { October ... we weren't really able to host any events ... in terms of } \\
\text { speakers and stuff because we couldn't get a room at the school." } \\
\text { (School 17) }\end{array}$ \\
\hline
\end{tabular}

STARS campaign, which combines a bottom-up approach enabled by top-down support to catalyze change, encapsulates these principles and has the potential to shift the culture and initiate a conversation with faculty and students about the importance of high-value care. ${ }^{11}$

Our evaluation of the STARS campaign identified several challenges and has informed further refinements needed to maximize its impact and ensure its sustainability. Although the campaign has sowed the seeds for grassroots student leadership for resource stewardship across Canada, much work is still needed to translate early wins into lasting change. Given the transient nature of medical students and the inevitable transition to clinical clerkship, when students generally have less time to devote to initiatives like STARS, the sustainability of the campaign ultimately requires the infusion of a new cohort of student leaders to expand on the efforts already underway and to lead new initiatives.

The next cohort of student leaders assembled at a Leadership Summit in February 2017 that marked the official launch of the next wave of STARS. Elements that enabled success were continued, and several key modifications based on the program evaluation were made. First, we dovetailed the Leadership Summit with the Choosing Wisely Canada National Meeting to expose students to the broader campaign. We also updated the Leadership Summit to include content on curriculum change because past STARS students identified challenges navigating this process. We also took a more proactive approach to identifying at least 1 faculty member at each school to help mentor students. Perhaps most important, we partnered with students to help codesign the Leadership Summit, and several students delivered presentations, including past STARS students discussing lessons learned from their experiences.

\section{Limitations}

Our study has several potential limitations. Since Choosing Wisely Canada led the evaluation of the STARS campaign, students may have treated the interview like an evaluation of their individual effectiveness, which may have rendered our findings susceptible to social desirability bias. The decision to combine student responses may have resulted in some loss of information. The self-reported nature of our data did not allow for evaluation of whether the initiatives led by students actually resulted in increased awareness or knowledge of resource stewardship principles among students at their local medical schools. Finally, the fact that the landscape nationally with respect to resource stewardship is rapidly shifting makes it difficult to know whether some of the curricular changes 
reported by students would have occurred independent of the STARS campaign. However, we believe that students' efforts at a minimum contributed to changes to the medical school curriculum.

\section{Conclusion}

By combining bottom-up, student-led change with topdown support from local faculty and the national Choosing Wisely Canada campaign, the STARS campaign led to the implementation of a wide range of awareness-building activities and early curricular change at medical schools across Canada. Our approach could be used by others to promote resource stewardship in medical education. In fact, programs modelled on STARS were launched in September 2017 in the Netherlands and will be launched this month in the United States. Next steps include building on the initial momentum created by the STARS campaign to sustain and spread local initiatives, and evaluating the longer-term impact of curricular change on medical student knowledge, skills and attitudes.

\section{References}

1. Levinson W, Huynh T. Engaging physicians and patients in conversations about unnecessary tests and procedures: Choosing Wisely Canada. CMAf 2014; $186: 325-26$

2. Chen C, Petterson S, Phillips R, et al. Spending patterns in region of residency training and subsequent expenditures for care provided by practicing physicians for Medicare beneficiaries. 7AMA 2014;312:2385-93.

3. Sirovich BE, Lipner RS, Johnston $M$, et al. The association between residency training and internists' ability to practice conservatively. FAMA Intern Med 2014;174:1640-8

4. Frank JR, Snell L, Sherbino J, editors. CanMEDS 2015 Physician Competency Framework. Ottawa: Royal College of Physicians and Surgeons of Canada; 2015.
5. Korenstein D. Charting the route to high-value care: the role of medical education. 7AMA 2015;314:2359-61.

6. Nasca TJ, Wess KB, Bagian JP. Improving clinical learning environments for tomorrow's physicians. NEngl 7 Med 2014;370:991-3.

7. Leep Hunderfund AN, Dyrbye LN, Starr SR, et al. Role modeling and regional health care intensity: U.S. medical student attitudes toward and experiences with cost-conscious care. Acad Med 2017;92:694-702.

8. Lakhani A, Lass E, Silverstein WK, et al. Choosing wisely for medical education: six things medical students and trainees should question. Acad Med 2016; 91:1374-8.

9. Levy AE, Shah N, Moriates C, et al. Fostering value in clinical practice among future physicians: time to consider COST. Acad Med 2014;89:1440.

10. Stammen LA, Stalmeijer RE, Paternotte E, et al. Training physicians to provide high-value, cost-conscious care: a systematic review. 7AMA 2015;314: 2384-400.

11. Moriates C, Wong BM. High-value care programmes from the bottom-up.. and the top-down. BM7 Qual Saf 2016;25:821-3.

Affiliations: Faculty of Medicine (Cardone, Cheung, Han, Alexander), University of Toronto; Choosing Wisely Canada (Born, Levinson, Wong), Li Ka Shing Knowledge Institute, St. Michael's Hospital; Institute of Health Policy, Management and Evaluation (Born); Department of Medicine (Levinson, Wong); Centre for Quality Improvement and Patient Safety (Wong), University of Toronto, Toronto, Ont.

Contributors: Franco Cardone, Daphne Cheung, Angela Han, Karen Born, Lisa Alexander and Brian Wong contributed substantially to the study conception and design. Franco Cardone, Daphne Cheung and Angela Han contributed substantially to data acquisition, and Franco Cardone, Daphne Cheung, Angela Han, Karen Born and Brian Wong contributed substantially to data analysis and interpretation. Franco Cardone, Daphne Cheung, Angela Han, Karen Born, Wendy Levinson and Brian Wong drafted the article and revised it critically for important intellectual content. Franco Cardone and Daphne Cheung contributed equally to the intellectual and other work associated with the role of first author. All of the authors gave final approval of the version to be published and agreed to be accountable for all aspects of the work.

Supplemental information: For reviewer comments and the original submission of this manuscript, please see www.cmajopen.ca/content/5/4/ E864/suppl/DC1. 